\title{
Effect of Climate Change and Anthropogenic Activities on Streamflow Indicators in a Tropical River Basin in Southern China
}

\author{
Fei Xu ${ }^{1}$, Lingling Zhao ${ }^{1}$, Cunwen Niu ${ }^{2, *}$ and Yaqin Qiu ${ }^{2}$ \\ 1 Guangdong Provincial Key Laboratory of Remote Sensing and Geographical Information System, Guangdong \\ Open Laboratory of Geospatial Information Technology and Application, Guangzhou Institute of Geography, \\ Guangdong Academy of Sciences, Guangzhou 510070, China; pinghuyu@outlook.com (F.X.); \\ linglingzhao@gdas.ac.cn (L.Z.) \\ 2 State Key Laboratory of Simulation and Regulation of Water Cycle in River Basin, China Institute of Water \\ Resources and Hydropower Research, Beijing 100038, China; qyqwd@126.com \\ * Correspondence: niucw@iwhr.com; Tel.: +86-10-6878-5606
}

check for updates

Citation: Xu, F.; Zhao, L.; Niu, C.; Qiu, Y. Effect of Climate Change and Anthropogenic Activities on Streamflow Indicators in a Tropical River Basin in Southern China. Water 2022, 14, 304. https://doi.org/ $10.3390 / \mathrm{w} 14030304$

Academic Editor: Renato Morbidelli

Received: 17 December 2021

Accepted: 17 January 2022

Published: 20 January 2022

Publisher's Note: MDPI stays neutral with regard to jurisdictional claims in published maps and institutional affiliations.

Copyright: (C) 2022 by the authors. Licensee MDPI, Basel, Switzerland. This article is an open access article distributed under the terms and conditions of the Creative Commons Attribution (CC BY) license (https:// creativecommons.org/licenses/by/ $4.0 /)$.

\begin{abstract}
Climate change and anthropogenic activities are the two main driving elements influencing changes in streamflow. Previous studies mainly focused on the impacts of climate change and anthropogenic activities on annual mean streamflow (AMS), ignoring annual maximum streamflow (Amax) and annual minimum streamflow (Amin). On the other hand, most previous studies attributed the impacts of climate change and anthropogenic activities synoptically. However, the separate influence mechanism among climatic variables, such as precipitation, temperature, sunshine duration change, direct human activities, and land use cover change, needs further analysis. We used the Water and Energy transfer Processes in Large River basin (WEP-L) model to quantify the impacts of climatic variables (precipitation, temperature, and sunshine duration) and anthropogenic activities (land use cover change (LUCC) and direct human activities (DHAs)) on streamflow in the Caojiang River Basin (CRB) with a tropical climate. The results indicate that anthropogenic activities play a major role in streamflow indictor variation. Of the investigated factors related to climate change, precipitation showed the greatest impact on streamflow variation. Notably, DHA contributed the most to the variation of the three streamflow indictors, followed by precipitation, temperature, and sunshine duration, while LUCC had a much lower impact on streamflow variation. This study investigated the response of different streamflow indicators (AMS, Amax, and Amin) to climate change and anthropogenic activities, and it is of value to watershed resource planning and management.
\end{abstract}

Keywords: streamflow indictors; climate change; anthropogenic activities; WEP-L model

\section{Introduction}

Climate change and anthropogenic activities are the two primary elements affecting the hydrological cycle [1-4]. Under the impacts of climate change and frequent anthropogenic activities, streamflow has changed [5-8]. Globally, changes in streamflow can result in both flooding and drought, resulting in casualties, property losses, and damage to the ecological environment [9-12]. Quantifying the impacts of climate change and anthropogenic activities on streamflow not only aids in understanding the relationship between hydrological processes with climate and environmental change, but also provides a scientific basis for water resource management.

The effects of climate change and anthropogenic activities on streamflow variation have been investigated and quantified worldwide [13-16] through statistical analysis, climate elasticity, and hydrological models. For example, Wang et al. [17] quantified the impact of climate change and anthropogenic activities on streamflow variation in the Songhua River Basin using a cumulative quantity method based on the slope change ratio. 
Zhang et al. [18] used eight time-trends to separate out the impacts of climate change and anthropogenic activities on streamflow variation in the Heihe River Basin while Li et al. [19] used the Budyko hypothesis to investigate the impacts of climate change and anthropogenic activities on streamflow variation in the Weihe River Basin. Further, Zhai and Tao [20] assessed the impacts of climate change and anthropogenic activities on streamflow in seven typical catchments across China using the Variable Infiltration Capacity (VIC) model while Ji and Duan [21] used the Soil and Water Assessment Tool (SWAT) model to quantify the main driving force of runoff change in the Weihe River Basin. However, the majority of streamflow variation-related studies have only investigated the synoptic impacts and influences of climate change and anthropogenic activities on streamflow variation [22-24].

Climate change is an umbrella term that relates to various changes in precipitation, temperature, and evapotranspiration through changes in atmospheric circulation, glaciers, and snow, thereby resulting in changes to streamflow [25-28]. Notably, anthropogenic activities include both direct and indirect impact impacts [29-32]. Direct impacts can be seen in river water intake, inter-basin water transfer, and water conservancy project regulation and storage [33-36] while indirect effects include changes in natural underlying surface conditions caused by population growth, urbanization development, soil and water conservation projects, and vegetation changes [37-40]. Therefore, there is a need to separate the impact mechanisms related to climatic elements, such as precipitation, temperature, and sunshine duration, from those related to both indirect human activities, such as land use/cover change (LUCC) and direct human activities (DHAs).

Notably, many studies have focused on the impacts of climate change and anthropogenic activities on annual mean streamflow (AMS) variations, but few have focused on annual maximum (Amax) and minimum (Amin) streamflow. Understanding the influences of climate variability and anthropogenic activities on Amax and Amin is helpful for managing flood risk and assessing environmental flow [41,42].

Within this context, our study was carried out in the Caojiang River Basin (CRB) in tropical South China, where water resources and the ecological environment are relatively sensitive to climate change and anthropogenic activities. The objectives of our study were to: (1) analyze the variation characteristics of AMS, Amax, and Amin; (2) use the detrended method and hydrological modeling to separate out the effects of precipitation, temperature, and sunshine duration on the three streamflow indicators; and (3) separate out the impacts of climate change and anthropogenic activities on the three streamflow indicators and further deduce the possible causes. This study highlights the response of different streamflow indicators (AMS, Amax, and Amin) to climate change and anthropogenic activities, and offers important information for mitigating future threats (e.g., drought and flooding), and it is of value to watershed resource planning and management.

\section{Materials and Methods}

\subsection{Study Area}

The CRB is located in the southwestern part of Guangdong Province (Figure 1), with a drainage area of $394 \mathrm{~km}^{2}$ (above the Dabai hydrological station). The basin is located in the tropical climate zone, with an annual mean precipitation of 2247.8 mm (from 1967-2018), primarily occurring from April to September (81.22\%). Forestland represents the primary land use in the basin, accounting for more than $75 \%$ of the CRB. Yellow and lateritic red soils form the main soil types of the basin, with 64.35 and $35.25 \%$, respectively.

The CRB contains one of the largest "water towers" in western Guangdong, with the combination of high-intensity anthropogenic activities and the occurrence of typhoons and rainstorms resulting in frequent flood disasters and serious social and economic losses. For example, on 21 September 2010, a flood with a return period of more than 200 years occurred in the CRB, owing to the influence of "Fanapi", with a 12-h rainfall of $677 \mathrm{~mm}$ recorded at Magui meteorological station, and a return period of 1000 years was a rare rainstorm. 

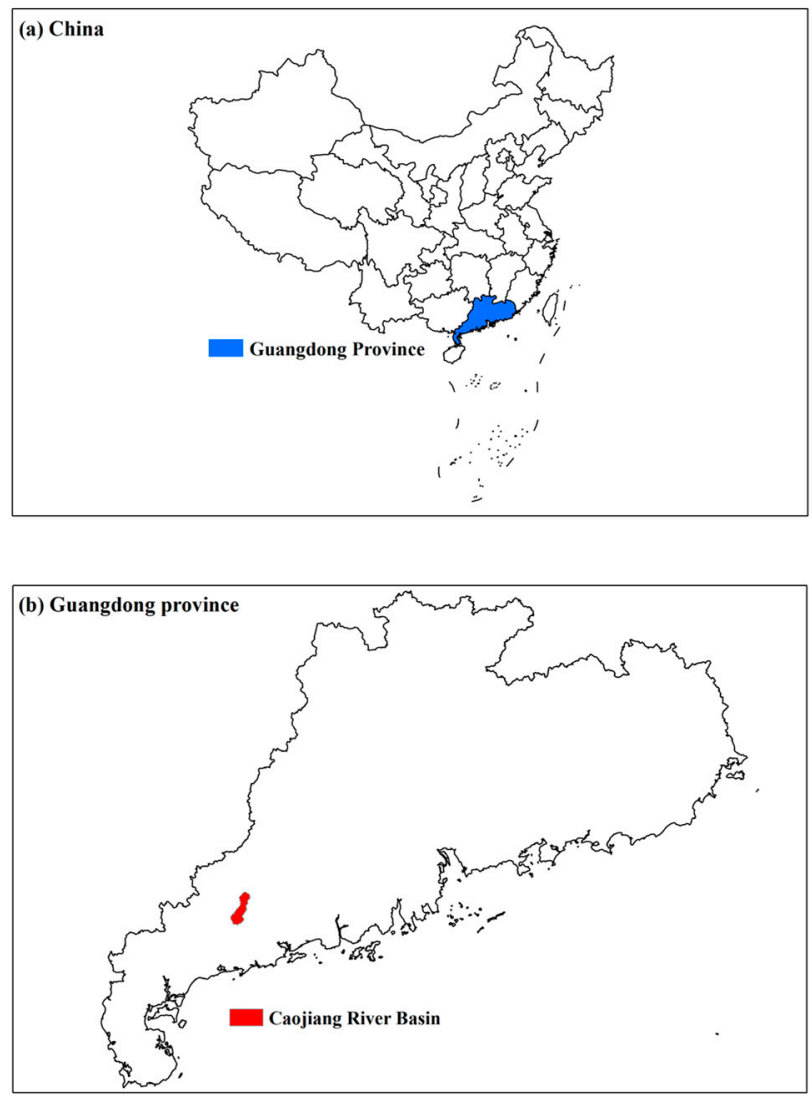

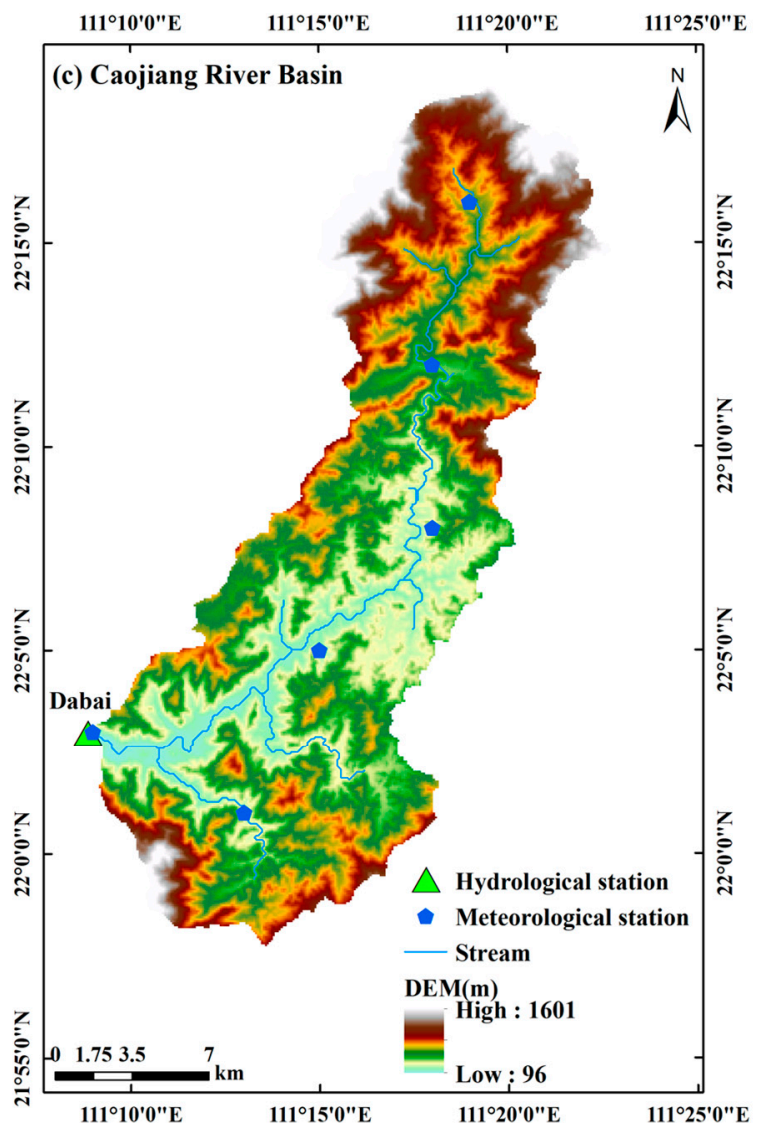

Figure 1. Location of (a) Guangdong Province, (b) the Caojiang River Basin (CRB), and (c) related hydrological and meteorological stations.

\subsection{Data Collection}

Daily climatic data (precipitation, mean air temperature, sunshine duration, relative humidity, and wind speed) from 1967 to 2018 were collected from six meteorological stations in the CRB (Figure 1), and downloaded from the National Meteorological Information Center of the China Meteorological Administration (https:/ / data.cma.cn/, (accessed on 1 September 2021)). We used the inverse distance square method to interpolate the calculation unit to obtain the surface climatic data. Daily streamflow data from 1967 to 2018 at the Dabai hydrological station were excerpted from the hydrological yearbook of the Pearl River Basin. Land-use data for 1980, 2000, and 2014 were downloaded from the land-use map of China (http:/ / www.resdc.cn, (accessed on 1 September 2021)) while population and GDP data were obtained from the Gaozhou Statistical Yearbook.

\subsection{Methodology}

\subsubsection{Trend Analysis and Abrupt Test}

We used the Mann-Kendall (MK) test $[43,44]$ to analyze hydrometeorological variation and trends (including precipitation, temperature, sunshine duration, AMS, Amax, Amin), using significance levels of 0.05 and 0.01 . The abrupt test on the three streamflow indicators was performed using the Pettitt test [45].

\subsubsection{Hydrological Model}

We used the Water and Energy transfer Processes in Large River basin (WEP-L) model to simulate hydrological processes in the CRB. The WEP-L model is a distributed hydrological model, which can simulate hydrological progresses includes evapotranspiration, infiltration, surface runoff, subsurface runoff, and groundwater flow. The Penman-Monteith equation was used to calculate evapotranspiration, excess infiltration during heavy rainfall 
was calculated by a generalized Green-Ampt model, and excess saturation during the remaining periods was calculated by balance analysis in unsaturated soil layers. Further, runoff routings for land and rivers were analyzed by applying a one-dimensional kinematic wave approach in a downstream direction while groundwater flows and multi-layered aquifers were individually and numerically simulated in mountainous and plains areas by considering water exchange between surface water, soil moisture, and runoff [46-49]. The hydrological model was calibrated and validated using the following three model performance indicators: the Nash-Sutcliffe efficiency coefficient (Nash), relative error (Re), and correlation coefficient (R) [48-50]. The WEP-L model can directly output daily, monthly, and annual streamflow, and has been widely used to investigate the separate contributions of climate change and anthropogenic activities to streamflow variation in the Haihe River Basin $[46,47]$ and the Yellow River Basin, China [51], and it was also successfully applied to the Beijiang River basin in tropical South China [52].

\subsubsection{Simulation Scenarios}

Using different climatic and LUCC conditions, we developed five simulation scenarios (S1-5, Table 1). By comparing the scenario (S1) with the other four scenarios (S2-5), we investigated and analyzed the impacts of the main climatic elements (precipitation, temperature, and sunshine duration) and LUCC on the CRB during the variation period. Notably, three main streamflow indicators were investigated (AMS, Amax, Amin), with possibly different variation periods for each indicator. Therefore, Table 1 lists only one indicator, and there should be 15 scenarios in the actual analysis process.

Table 1. Description of the five simulation scenarios.

\begin{tabular}{|c|c|c|c|c|c|c|}
\hline Scenario & Precipitation & Temperature & $\begin{array}{l}\text { Sunshine } \\
\text { Duration }\end{array}$ & $\begin{array}{l}\text { LUCC } \\
\text { during }\end{array}$ & Streamflow & Objectives \\
\hline S1 & Real & Real & Real & 1980 & Simulated by WEP-L & Analyze the effects of climate change \\
\hline S2 & Detrended & Real & Real & 1980 & Simulated by WEP-L & Analyze the effects of precipitation \\
\hline S3 & Real & Detrended & Real & 1980 & Simulated by WEP-L & Analyze the effects of temperature \\
\hline S4 & Real & Real & Detrended & 1980 & Simulated by WEP-L & Analyze the effects of sunshine duration \\
\hline S5 & Real & Real & Real & 2014 & Simulated by WEP-L & Analyze the effects of LUCC \\
\hline
\end{tabular}

To separate out the effects of the main climatic elements, we removed precipitation, temperature, and sunshine duration trends during the variation period. By comparing scenario S1 with the detrended scenarios (S2-S4), the individual effects of precipitation, temperature, and sunshine duration could be analyzed. The trends of the climatic elements were removed using the following steps:

The linear trend for climatic factors during the variation period was obtained by linear regression:

$$
\operatorname{Line}\left(Y_{t}\right)=a t+b
$$

where $Y_{t}$ is the meteorological series; $t=1,2, \ldots, N$; $N$ is the number of years of the variation period; and $\mathrm{a}$ and $\mathrm{b}$ are the slope and intercept of the line, respectively.

The yearly detrended data series $\left(Y_{t}^{\prime}\right)$ were calculated using the following equation:

$$
Y_{t}^{\prime}=Y_{t}-a t
$$

The daily detrended series $\left(D_{t}^{\prime}(i)\right)$ were calculated as follows:

$$
D_{t}^{\prime}(i)=D_{t}(i) \times \frac{Y_{t}^{\prime}}{Y_{t}}
$$

where $i=1,2, \ldots, 365 / 366$, and $D_{t}(i)$ is the real daily meteorological series. 


\subsubsection{Contribution Evaluation}

First, we applied the Pettitt test to determine the abrupt points of AMS, Amax, and Amin. The study period (1967-2018) was divided into a baseline and a variation period. Second, we used the daily observed streamflow data to calibrate and validate the WEP-L model. Third, we combined the different scenarios with the WEP-L model to simulate the streamflow for each scenario. Fourth, we investigated the contributions of climate variability (precipitation, temperature, and sunshine duration) and anthropogenic activities (LUCC and DHA) to variations in AMS, Amax, and Amin. The framework of the implemented methodology is shown in Figure 2.

\begin{tabular}{|c|c|}
\hline \multirow[t]{2}{*}{ Step1:Data preparation } & Observed streamflow \\
\hline & 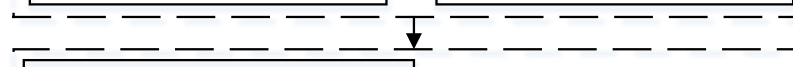 \\
\hline \multirow[t]{2}{*}{ Step2:Trend analysis } & $\begin{array}{l}\text { Precipitation, temperature } \\
\text { Sunshine duration }\end{array}$ \\
\hline & 二ニニ二二ニ二士ニ二ニ二ニ二 \\
\hline \multirow[t]{2}{*}{ Step3:Abrupt test } & $\begin{array}{c}\text { Apply Pettitt test to determine the abrupt points of } \\
\text { AMS, Amax, Amin }\end{array}$ \\
\hline & $\begin{array}{l}-\overline{-}-\overline{-}-\overline{-}----\overline{-} \\
--\overline{-}-\overline{-}\end{array}$ \\
\hline \multirow[t]{2}{*}{$\begin{array}{l}\text { Step4:Climatic } \\
\text { elements detrending }\end{array}$} & Daily climatic data series were detrended \\
\hline & $\begin{array}{l}-------\overline{-}----- \\
--\overline{-}-\overline{-}\end{array}$ \\
\hline $\begin{array}{l}\text { Step5:Performance of } \\
\text { the WEP-L model }\end{array}$ & $\begin{array}{l}\text { Calibrated and validated the WEP-L model using } \\
\text { daily streamflow data by Nash, Re, R indicators }\end{array}$ \\
\hline $\begin{array}{l}\text { Step6:Contribution } \\
\text { evaluation }\end{array}$ & $\begin{array}{c}\text { Investigated the contributions of climate change } \\
\text { (precipitation, temperature, and sunshine duration) } \\
\text { and human activities (LUCC and DHA) on } \\
\text { variations in AMS, Amax, and Amin. }\end{array}$ \\
\hline
\end{tabular}

Figure 2. Framework of the implemented methodology.

Differences in the streamflow between the two periods were calculated by the following equation:

$$
\Delta \bar{S}=\bar{S}_{v}-\bar{S}_{b}
$$

where $\Delta \bar{S}$ is the total change in streamflow, and $\bar{S}_{v}$ and $\bar{S}_{b}$ are the streamflow values during the change and baseline periods, respectively. For the given river basin, the total variations in streamflow were the result of the joint impacts of climate change and anthropogenic activities. Thus, $\Delta \bar{S}$ can be calculated as follows:

$$
\Delta \bar{S}=\bar{S}_{C C}+\bar{S}_{H A}=\bar{S}_{P}+\bar{S}_{T}+\bar{S}_{S D}+\bar{S}_{L U C C}+\bar{S}_{D H A},
$$

where $\bar{S}_{C C}, \bar{S}_{H A}, \bar{S}_{P}, \bar{S}_{T}, \bar{S}_{S D}, \bar{S}_{L U C C}$, and $\bar{S}_{D H A}$ are the streamflow variations caused by climate variability, anthropogenic activities, precipitation, temperature, sunshine duration, LUCC, and DHA, respectively.

Furthermore:

$$
\eta_{C C}=\frac{\bar{S}_{C C}}{\Delta \bar{S}} \times 100 \%=\eta_{P}+\eta_{T}+\eta_{S D}=\frac{\bar{S}_{P}}{\Delta \bar{S}} \times 100 \%+\frac{\bar{S}_{T}}{\Delta \bar{S}} \times 100 \%+\frac{\bar{S}_{S D}}{\Delta \bar{S}} \times 100 \%
$$




$$
\eta_{H A}=\frac{\bar{S}_{H A}}{\Delta \bar{S}} \times 100 \%=\eta_{L U C C}+\eta_{D H A}=\frac{\bar{S}_{L U C C}}{\Delta \bar{S}} \times 100 \%+\frac{\bar{S}_{D H A}}{\Delta \bar{S}} \times 100 \%
$$

where $\eta_{C C}, \eta_{H A}, \eta_{P}, \eta_{T}, \eta_{S D}, \eta_{L U C C}$, and $\eta_{D H A}$ are the percentage contributions of climate variability, anthropogenic activities, precipitation, temperature, sunshine duration, LUCC, and DHA to streamflow variations, respectively. Each factor was calculated as follows:

$$
\begin{gathered}
\bar{S}_{P}=\bar{S} 2-\bar{S} 1 \\
\bar{S}_{T}=\bar{S} 3-\bar{S} 1 \\
\bar{S}_{S D}=\bar{S} 4-\bar{S} 1 \\
\bar{S}_{C C}=\bar{S}_{P}+\bar{S}_{T}+\bar{S}_{S D} \\
\bar{S}_{H A}=\Delta \bar{S}-\bar{S}_{C C} \\
\bar{S}_{L U C C}=\bar{S} 5-\bar{S}_{1} \\
\bar{S}_{D H A}=\bar{S}_{H A}-\bar{S}_{L U C C}
\end{gathered}
$$

where $\bar{S} 1, \bar{S} 2, \bar{S} 3, \bar{S} 4$, and $\bar{S} 5$ correspond to the mean streamflow under scenarios $\mathrm{S} 1, \mathrm{~S} 2, \mathrm{~S} 3$, S4, and S5, respectively. The contribution of each factor was calculated using Equations (6) and (7).

\section{Results}

\subsection{Changes in Climatic Elements and Streamflow}

We investigated temporal variations in precipitation, temperature, and sunshine duration in the CRB from 1967-2018 (Figure 3). The results indicate that precipitation increased slightly at a rate of $24.8 \mathrm{~mm}$ /decade while annual mean temperature increased significantly $(p<0.0001)$ at a rate of $0.23{ }^{\circ} \mathrm{C} /$ decade, and sunshine duration decreased by $-0.03 \mathrm{~h}$ /decade. Of the three investigated streamflow indicators, AMS and Amin showed positive trends of 0.34 and $0.13 \mathrm{~m}^{3} / \mathrm{s}$ / decade, respectively, while Amax decreased at a rate of $-25.02 \mathrm{~m}^{3} / \mathrm{s} /$ decade (Figure 4 ).

The Pettitt test showed that abrupt changes in AMS, Amax, and Amin occurred in 1985, 1981, and 1982, respectively. Therefore, the baseline period for AMS, Amax, and Amin was set at 1967-1985, 1967-1981, and 1967-1982, respectively, with variation periods of 1986-2018, 1982-2018, and 1983-2018, respectively. A comparison of the two periods (Table 2) indicates that AMS and Amax decreased (AMS by $5.86 \%$ from 20.3 to $19.1 \mathrm{~m}^{3} / \mathrm{s}$, Amax by $36.19 \%$ from 353.6 to $225.6 \mathrm{~m}^{3} / \mathrm{s}$ ) while Amin increased by $28.82 \%$, from 3.0 to $3.9 \mathrm{~m}^{3} / \mathrm{s}$. These results indicate that Amax and Amin showed greater variation than AMS. However, the climatic factors of precipitation and sunshine duration showed a slight decline together with an increase in temperature but with change rates of less than $\pm 5 \%$. Streamflow showed greater variation than the climatic factors, indicating that other factors affect streamflow variation.

Table 2. Average streamflow, precipitation, temperature, and sunshine duration values and change rates in the baseline and variation periods in the Caojiang River Basin (CRB).

\begin{tabular}{cccccccccc}
\hline & \multicolumn{3}{c}{ AMS } & \multicolumn{3}{c}{ Amax } & & Amin \\
\cline { 2 - 10 } & $\mathbf{1 9 6 7 - 1 9 8 5}$ & $\mathbf{1 9 8 6 - 2 0 1 8}$ & $\begin{array}{c}\text { Chang } \\
\text { Rate (\%) }\end{array}$ & $\mathbf{1 9 6 7 - 1 9 8 1}$ & $\mathbf{1 9 8 2 - 2 0 1 8}$ & $\begin{array}{c}\text { Chang } \\
\text { Rate (\%) }\end{array}$ & 1967-1982 & 1983-2018 & $\begin{array}{c}\text { Chang } \\
\text { Rate (\%) }\end{array}$ \\
\hline Streamflow $\left(\mathrm{m}^{3} / \mathrm{s}\right)$ & 20.3 & 19.1 & -5.86 & 353.6 & 225.6 & -36.19 & 3.0 & 3.9 & 28.82 \\
AAP $\left(\mathrm{mm}^{\circ}\right)$ & 2273.9 & 2232.8 & -1.81 & 2273.1 & 2237.5 & -1.56 & 2257.4 & 2243.5 & -0.62 \\
AAT $\left({ }^{\circ} \mathrm{C}\right)$ & 22.18 & 22.90 & 3.24 & 22.20 & 22.81 & 2.74 & 22.22 & 22.82 & 2.72 \\
AASD $(\mathrm{h})$ & 4.99 & 4.90 & -1.88 & 5.09 & 4.87 & -4.35 & 5.06 & 4.88 & -3.59 \\
\hline
\end{tabular}

Note: AAP means annual average precipitation; AAT means annual average temperature; AASD means annual average sunshine duration. 

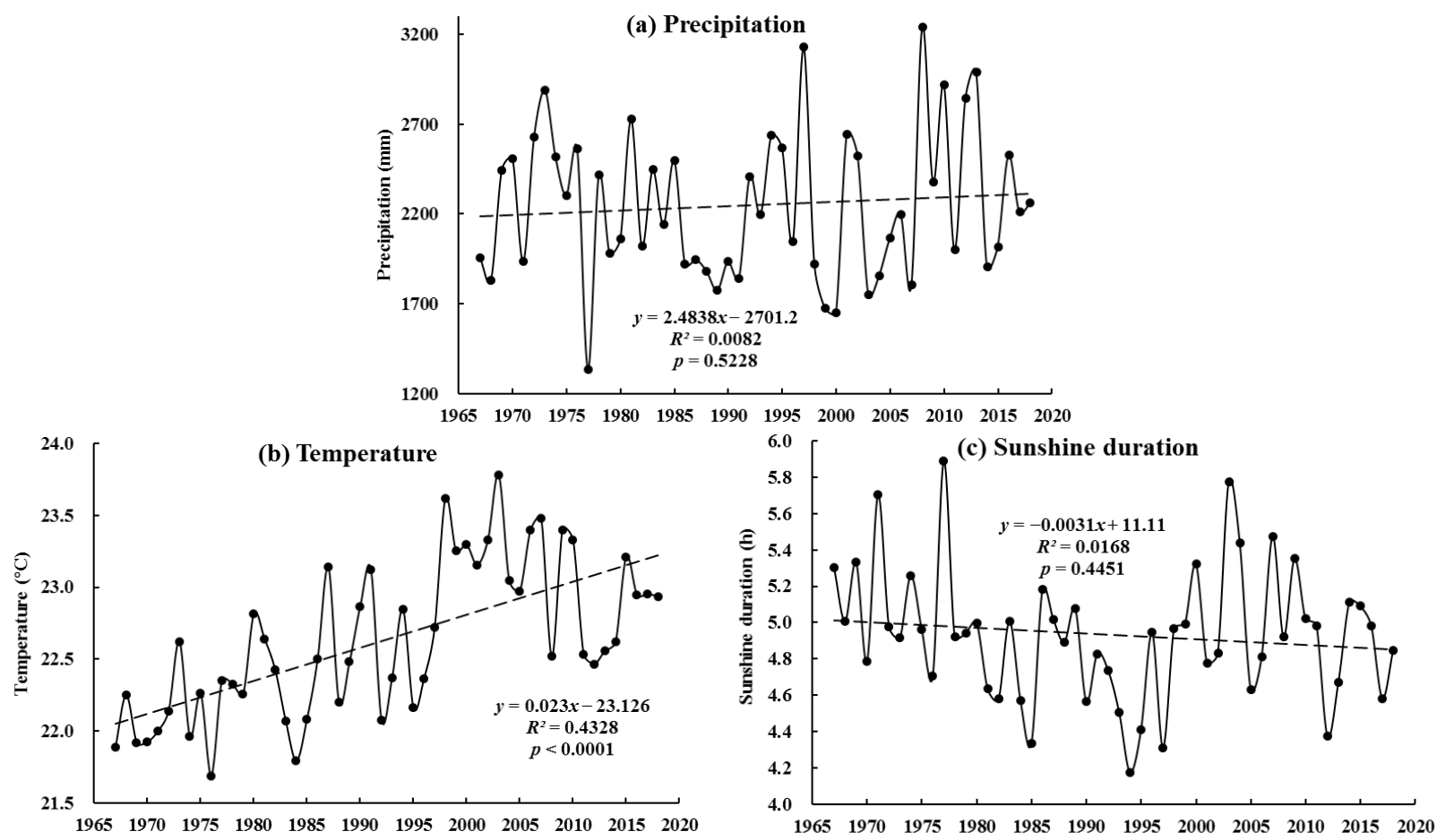

Figure 3. Temporal variations in (a) precipitation, (b) temperature, and (c) sunshine duration in the Caojiang River Basin (CRB) from 1967-2018. The dotted line is the trend line.
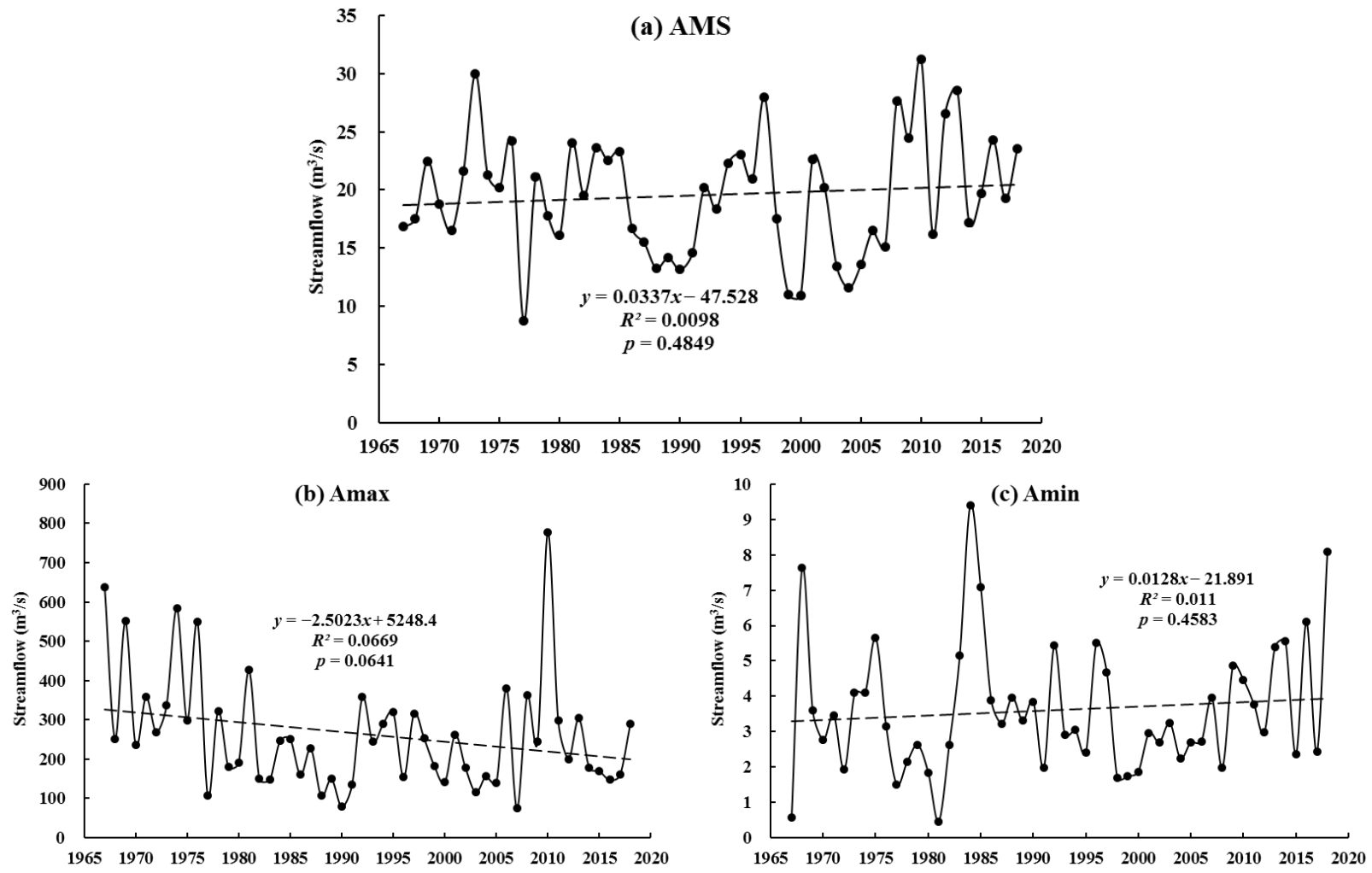

Figure 4. Temporal variations in (a) annual mean streamflow (AMS), (b) annual maximum streamflow (Amax), and (c) annual minimum streamflow (Amin) in the Caojiang River Basin (CRB) from 19672018. The dotted line is the trend line. 


\subsection{Performance of the WEP-L Model}

In this study, we calibrated and validated the WEP-L model using daily streamflow data from the AMS baseline period. As this was the longest period, a good performance of the WEP-L model would be indicative of credible simulated Amax and Amin results. The periods 1967-1977 and 1978-1985 were chosen as the calibration and validation periods, respectively, and a comparison was drawn between the observed and simulated daily streamflow at the Dabai hydrological station (Figure 5). Notably, the simulated streamflow corresponded well with the observed streamflow. Our results showed Nash, Re, and R values of $0.72,2.05 \%$, and 0.85 , respectively, during the calibration period; and $0.73,-1.00 \%$, and 0.88 , respectively, during the validation period. Regardless of the period, all Nash values were higher than 0.70 while Re values were less than $\pm 3.0 \%$, and $R$ values were greater than 0.85 . These results indicate that the model performed well in the simulated daily streamflow in the CRB and could be used to simulate other hydrological processes in the CRB.
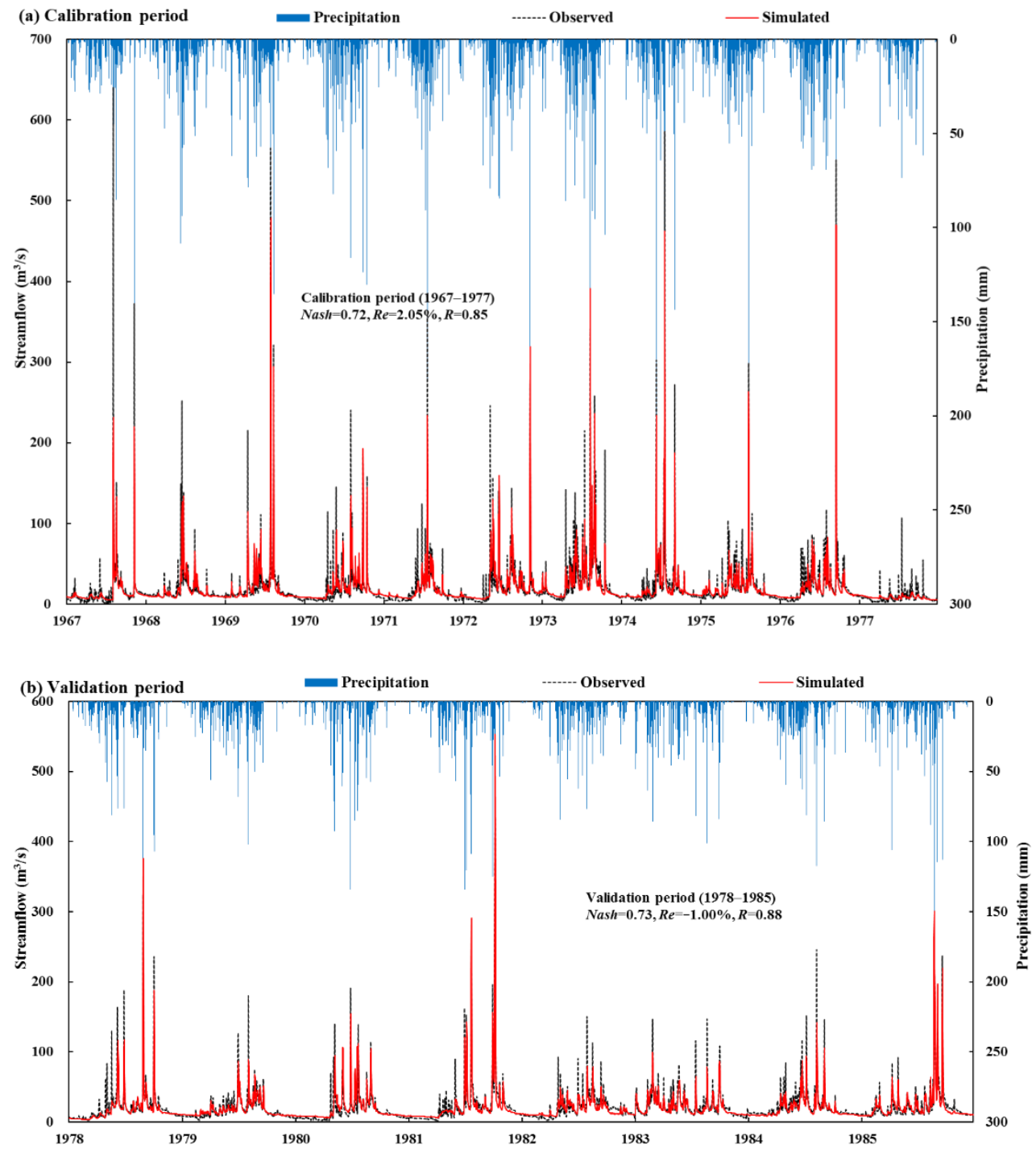

Figure 5. Comparison between the observed and simulated daily streamflow of the Dabai hydrological station during (a) the calibration and (b) validation periods.

\subsection{Contribution of Individual Factors to Streamflow Variation}

Using Equations (4)-(14), we calculated the effect and contribution of precipitation, temperature, sunshine duration, climate change, LUCC, DHA, and human activities on AMS, Amax, and Amin variation (Table 3). Regarding variation in AMS, our results indicate 
that climate change and anthropogenic activities decreased AMS by 0.55 and $0.64 \mathrm{~m}^{3} / \mathrm{s}$, respectively, and accounted for 46.11 and $53.89 \%$ of the variation, respectively. Precipitation and temperature reduced AMS by 0.57 and $0.02 \mathrm{~m}^{3} / \mathrm{s}$, and accounted for 47.88 and $1.95 \%$ of the variation, respectively. Sunshine duration increased AMS by $0.04 \mathrm{~m}^{3} / \mathrm{s}$, accounting for $-3.72 \%$ of the variation. Of the two anthropogenic-related elements, LUCC increased AMS by $0.03 \mathrm{~m}^{3} / \mathrm{s}$, accounting for $-2.56 \%$ of the changes in AMS, while DHA reduced AMS by $0.67 \mathrm{~m}^{3} / \mathrm{s}$, accounting for $56.45 \%$ of the AMS variation.

Table 3. Contributions of climate change (including three major climatic factors, precipitation, temperature, and sunshine duration), land use/cover change (LUCC), and direct human activities (DHAs) to three streamflow indictors (AMS, Amin, Amax) in the Caojiang River Basin (CRB).

\begin{tabular}{|c|c|c|c|c|c|c|c|}
\hline & \multirow{2}{*}{ Factors } & \multicolumn{2}{|c|}{ AMS } & \multicolumn{2}{|c|}{ Amax } & \multicolumn{2}{|c|}{ Amin } \\
\hline & & $\Delta S\left(\mathrm{~m}^{3} / \mathrm{s}\right)$ & Contribution & $\Delta S\left(\mathrm{~m}^{3} / \mathrm{s}\right)$ & Contribution & $\Delta S\left(\mathrm{~m}^{3} / \mathrm{s}\right)$ & Contribution \\
\hline \multirow{4}{*}{$\mathrm{CC}$} & Precipitation & -0.57 & $47.88 \%$ & -42.77 & $33.42 \%$ & -0.53 & $-60.82 \%$ \\
\hline & Temperature & -0.02 & $1.95 \%$ & -0.48 & $0.37 \%$ & -0.01 & $-0.79 \%$ \\
\hline & Sunshine duration & 0.04 & $-3.72 \%$ & 0.61 & $-0.48 \%$ & 0.02 & $2.42 \%$ \\
\hline & Total & -0.55 & $46.11 \%$ & -42.63 & $33.32 \%$ & -0.51 & $-59.19 \%$ \\
\hline \multirow{2}{*}{ HA } & LUCC & 0.03 & $-2.56 \%$ & 0.63 & $-0.50 \%$ & 0.01 & $0.74 \%$ \\
\hline & DHA & -0.67 & $56.45 \%$ & -85.97 & $67.18 \%$ & 1.37 & $158.45 \%$ \\
\hline
\end{tabular}

Note: CC means climate change; HA means human activities.

For Amax, climate change and anthropogenic activities resulted in a reduction of 42.63 and $85.34 \mathrm{~m}^{3} / \mathrm{s}$, and accounted for 33.32 and $66.68 \%$ of the variation, respectively. Furthermore, precipitation and temperature reduced Amax by 42.77 and $0.48 \mathrm{~m}^{3} / \mathrm{s}$, accounting for 33.42 and $0.37 \%$ of the variation in Amax, respectively. Sunshine duration increased Amax by $0.61 \mathrm{~m}^{3} / \mathrm{s}$ and contributed $-0.48 \%$ to the Amax variation. In addition, LUCC increased AMS by $0.63 \mathrm{~m}^{3} / \mathrm{s}$, accounting for $-0.50 \%$ of the variation, while DHA reduced Amax by $85.97 \mathrm{~m}^{3} / \mathrm{s}$, accounting for $67.18 \%$ of the variation.

For Amin, climate change resulted in a $0.51 \mathrm{~m}^{3} / \mathrm{s}$ decrease, accounting for $-59.19 \%$ of the variation in Amin, while anthropogenic activities led to a $1.38 \mathrm{~m}^{3} / \mathrm{s}$ increase, and accounted for $159.19 \%$ of the variation in Amin. The contribution rates of precipitation, temperature, and sunshine duration were $-60.82,-0.79$, and $2.42 \%$, respectively, and LUCC and DHA contributed 0.74 and $158.45 \%$ to the Amin increase, respectively.

These results indicate that human activities play a major role in the variations of the three investigated streamflow indicators. Of the studied factors, DHA was the primary cause of changes in the streamflow indicators, followed by precipitation, while the contribution rates of the other three factors were much lower.

\section{Discussion}

\subsection{Impacts of Climate Change}

In this study, we investigated the impacts of climate variability and anthropogenic activities on streamflow variation, using AMS, Amax, and Amin. Climate change was further investigated by separating climatic factors into precipitation, temperature, and sunshine hours while anthropogenic activities were investigated in terms of LUCC and DHA. Based on the results, we discuss the impact of each individual factor on streamflow variation.

Notably, the effect of precipitation on AMS, Amax, and Amin variation was much higher than that of temperature and sunshine duration (Table 3). We used a Pearson correlation $[24,53]$ to further analyze the impact of precipitation, temperature, and sunshine duration on the three streamflow indicators (AMS, Amin, and Amax) (Table 4). The results indicate that AMS was positively correlated with annual total precipitation (ATP), annual maximum 1-day precipitation ( $\mathrm{Rx} 1 \mathrm{day}$ ), and annual maximum consecutive 5-day precipitation (Rx5 day), with coefficients of $0.91,0.54$, and 0.57 , respectively $(p<0.01)$. Furthermore, 
AMS was negatively correlated with annual mean temperature (AMT) $(R=-0.20, p>0.05)$ and annual mean sunshine duration (AMSD) $(R=-0.45, p<0.01)$. Amax was positively correlated with ATP $(R=0.50, p<0.01)$, Rx1 day $(R=0.57, p<0.01)$, and $R x 5$ day $(R=0.79$, $p<0.01)$ but negatively correlated with AMT $(R=-0.31, p<0.05)$ and AMSD $(R=-0.03$, $p>0.05)$. Amin was positively correlated with ATP and Rx1 day but negatively correlated with Rx5 day, AMT, and AMSD, and none of them passed the significant test $(p>0.05)$. The coefficients between the three streamflow indictors and precipitation indicators (ATP, Rx1 day, and Rx5 day) were much higher than those related to temperature (AMT) and sunshine duration (AMSD). These results indicate that the impact of climate variability on variations in streamflow is primarily related to the effect of precipitation. Results from other studies have also shown that, of the influencing factors of climate change, precipitation has the greatest impact on streamflow variation $[21,22,32,39]$.

Table 4. Pearson's correlation coefficients between streamflow and various climatic factors in the Caojiang River Basin (CRB) from 1967-2018.

\begin{tabular}{cccccc}
\hline Streamflow & ATP & RX1 Day & RX5 Day & AMT & AMSD \\
\hline AMS & $0.91^{* *}$ & $0.54^{* *}$ & $0.57^{* *}$ & -0.20 & $-0.45^{* *}$ \\
Amax & $0.50^{* *}$ & $0.57^{* *}$ & $0.79^{* *}$ & $-0.31^{*}$ & -0.03 \\
Amin & 0.12 & 0.08 & -0.02 & -0.22 & -0.16 \\
\hline
\end{tabular}

Note: ATP: annual total precipitation, mm; RX1 day: Maximum 1-day precipitation, mm, Annual maximum 1-day precipitation; RX5 day: Maximum 5-day precipitation, mm, Annual maximum consecutive 5-day precipitation; Maximum number of consecutive dry days; AMT: annual mean temperature; AMSD: annual mean sunshine duration. * means a significant level of $0.05 ;{ }^{* *}$ means a significant level of 0.01 .

\subsection{Anthropogenic-Related Impacts}

Anthropogenic activities contributed $53.89,66.68$, and $159.19 \%$ to the variations in AMS, Amax, and Amin in the CRB, respectively. These results indicate that anthropogenic activities play a major role in the streamflow variation, which corresponds to the results of other studies $[4,32,42]$. In this study, we further divided anthropogenic activities into LUCC and DHA. Notably, LUCC increased AMS, Amax, and Amin, accounting for $-2.56,-0.50$, and $0.74 \%$ of the variation, respectively. These impacts were much lower than the impacts related to DHA, with DHA accounting for 56.45, 67.18, and $158.45 \%$ of the variation in AMS, Amax, and Amin, respectively.

We collected and investigated the change rates of the LUCC data from three periods $(1980,2000,2014)$ in the CRB (Figure 6 and Table 5). Regarding LUCC patterns, forests and farmland were predominant in the $\mathrm{CRB}$, accounting for 75 and $18 \%$ of the total land-use area. However, the rate of LUCC change during 1980 and 2014 was very small, with farmland, forest, and grassland decreasing by only $-0.28,-0.03$, and $-2.58 \%$, respectively. In contrast, we recorded a clear increase in water bodies and residential areas of 45.33 and $77.75 \%$, respectively. The decrease in forests and grasslands together with an increase in water bodies and residential areas reduces evapotranspiration and infiltration rates, leading to increased streamflow, while the decrease in farmland reduction leads to a decrease in streamflow [27,33]. Overall, LUCC increased AMS, Amax, and Amin, as AMS and Amax declined, so the contribution rate of LUCC to them was negative. While LUCC had a positive Amin because it increased during the variation period compared to the baseline period, the contribution rate of LUCC to the three streamflow indictors was much lower owing to a low rate of change. 

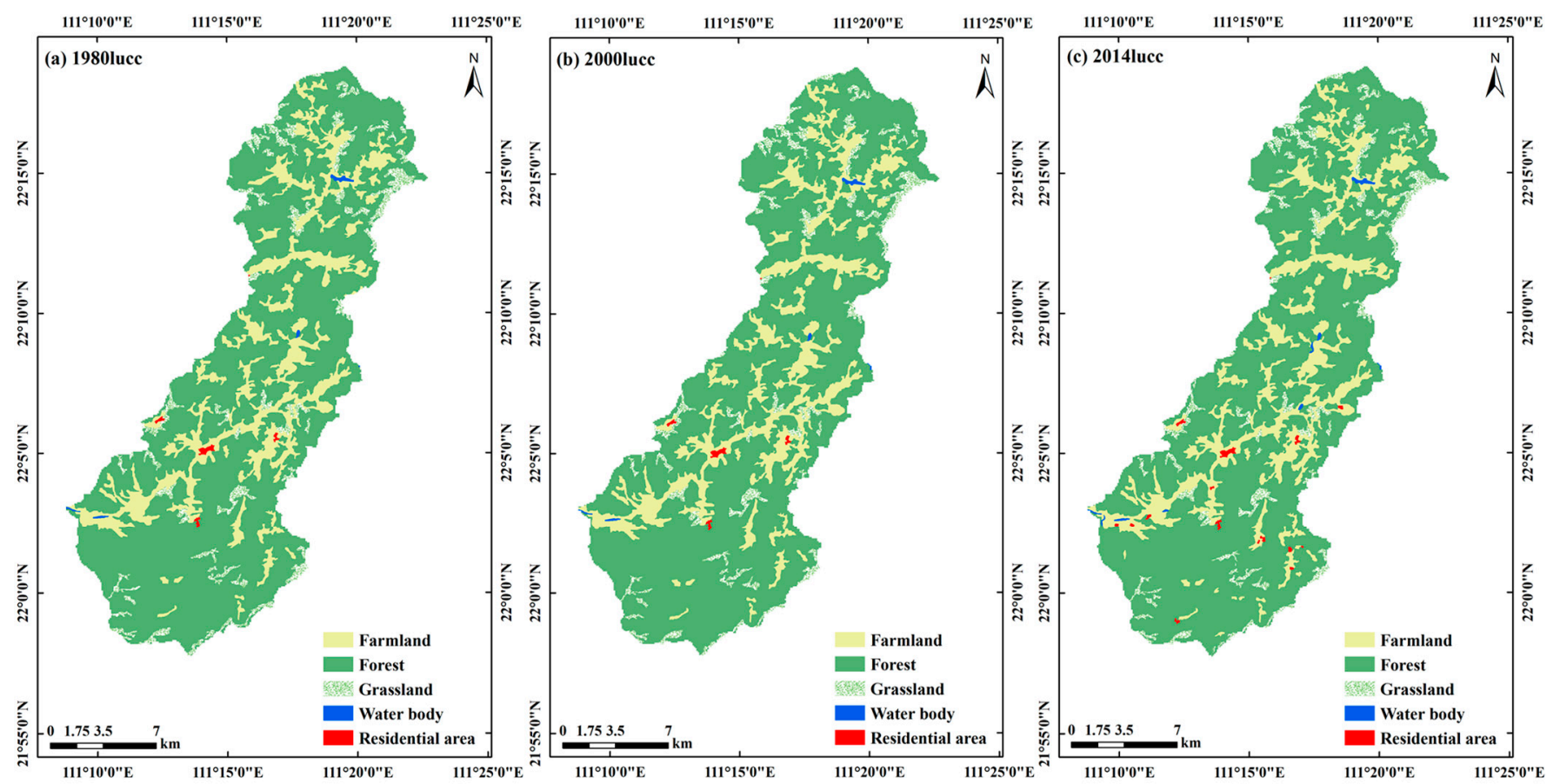

Figure 6. Map of land use/cover change (LUCC) in the Caojiang River Basin (CRB) in (a) 1980, (b) 2000, and (c) 2014 .

Table 5. Land-use areas and change rates across different periods.

\begin{tabular}{cccccc}
\hline LUCC & $\mathbf{1 9 8 0} \mathbf{( k m}^{\mathbf{2}}$ & $\left.\mathbf{2 0 0 0} \mathbf{( k m}^{\mathbf{2}}\right)$ & $\left.\mathbf{2 0 1 4} \mathbf{( k m}^{\mathbf{2}}\right)$ & $\begin{array}{c}\mathbf{1 9 8 0 - 2 0 0 0} \\
\text { Change Rate }\end{array}$ & $\begin{array}{c}\mathbf{1 9 8 0 - 2 0 1 4} \\
\text { Change Rate }\end{array}$ \\
\hline Farmland & 71.15 & 71.12 & 70.95 & $-0.04 \%$ & $-0.28 \%$ \\
Forest & 294.47 & 295.47 & 294.38 & $0.34 \%$ & $-0.03 \%$ \\
Grassland & 25.35 & 24.37 & 24.70 & $-3.89 \%$ & $-2.58 \%$ \\
Water body & 0.70 & 0.72 & 1.02 & $1.93 \%$ & $45.33 \%$ \\
Residential area & 0.81 & 0.81 & 1.44 & $-0.18 \%$ & $77.75 \%$ \\
\hline
\end{tabular}

The contribution rates of the different factors (Table 3) indicate that DHA is the major factor influencing variations in streamflow. With the intensification of human activities, DHAs, such as water consumption and reservoir operation, have a direct impact on streamflow $[22,36]$. As our study did not include water use data, we used population and GDP data to indirectly reflect water consumption. The CRB belongs to the city of Gaozhou, and changes in the population and GDP in Gaozhou City are reflective of variations in the population and GDP in the CRB (Figure 7). Population and GDP increased significantly, especially after 1985. The population increased at rates of 13.9 and 20.8 thousand people per year during the baseline and variation periods, respectively. With GDP increasing at rates of 16.9 and 1725.8 million yuan/year before and after 1985, population growth and economic development have resulted in increased water demand for human life and industry, and hence, greatly decreased streamflow.

Reservoir regulations and storage can affect natural hydrological processes [22,42]. Specifically, the storage of reservoir water during flood seasons can reduce Amax while the regulation of streamflow through reservoir release during the dry season can increase Amin [34]. To investigate these effects, we tracked the Amax and Amin occurrence dates from the Dabai hydrological station from 1967-2018 (Figure 8). The mean occurrence dates of Amax and Amin during the study period were 210 and 115, respectively, equating to July and April. During the baseline and variation periods, the mean occurrence dates of Amax were 224 and 205, equating to August and July, and 126 and 111 in Amin, equating to May and April, respectively. Therefore, Amax occurred in July and August, and Amin in 
April and May. Typhoons and rainstorms frequently occur in July and August in the CRB, causing floods. Before the flood season, reservoirs are typically empty or have a minimum water level (Figure 9a). This allows for the storage of water during flood events, which significantly reduces Amax in July and August. Furthermore, April and May are important water demand periods for rice and other crops, as reservoirs are needed for agricultural irrigation (Figure 9b), thereby increasing Amin. Within this context, the regulation of reservoirs and storage can reduce the risk of downstream flooding in the rain season and increase streamflow for irrigation in the dry season [2,34]. The findings of other related studies have also shown that reservoir regulation and storage have important effects on streamflow $[2,25,42]$.

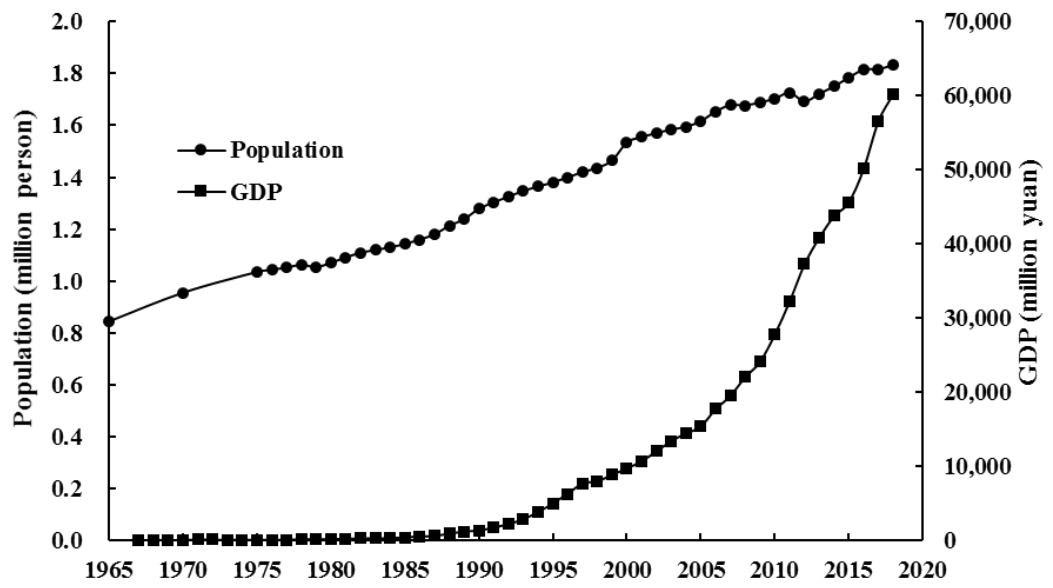

Figure 7. Changes in population and GDP data of Gaozhou City, China.

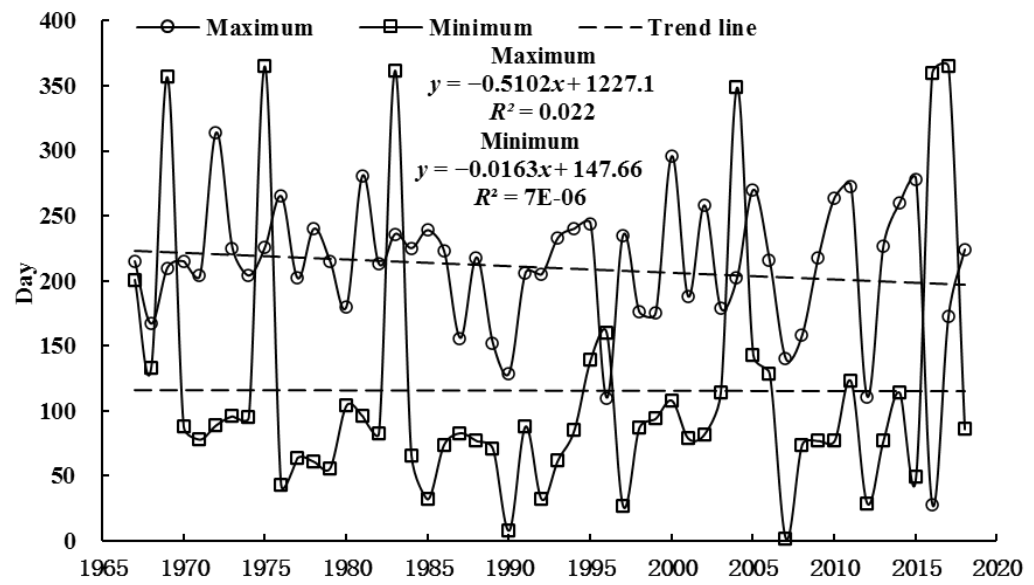

Figure 8. Temporal variations in the occurrence dates of Amax and Amin at the Daibai hydrological station from 1967-2018.

However, there are some uncertainties in this study. First, the observed climatic data may not fully reflect the real meteorological information. Although there are six meteorological stations in the $\mathrm{CRB}$, on average, one meteorological station controls $65.67 \mathrm{~km}^{2}$ and its control area is significantly lower than the average value of national meteorological stations (higher than $10,000 \mathrm{~km}^{2}$ ), and they still cannot fully reflect the actual meteorology of the basin. Second, observation errors may be present in streamflow data. Especially, the early observation equipment and technology are relatively backward, which may lead to observation errors. Third, due to the lack of LUCC data, we only used one period (1980) LUCC to simulate the hydrological progresses of the CRB during the baseline period, which may cause analog distortion, as show in Figure 5a, during which the WEP-L model underestimated some extreme peak streamflow, especially in 1967, 1971, 1974, and 1976. Further in-depth discussion is needed in future research to reduce uncertainty. 

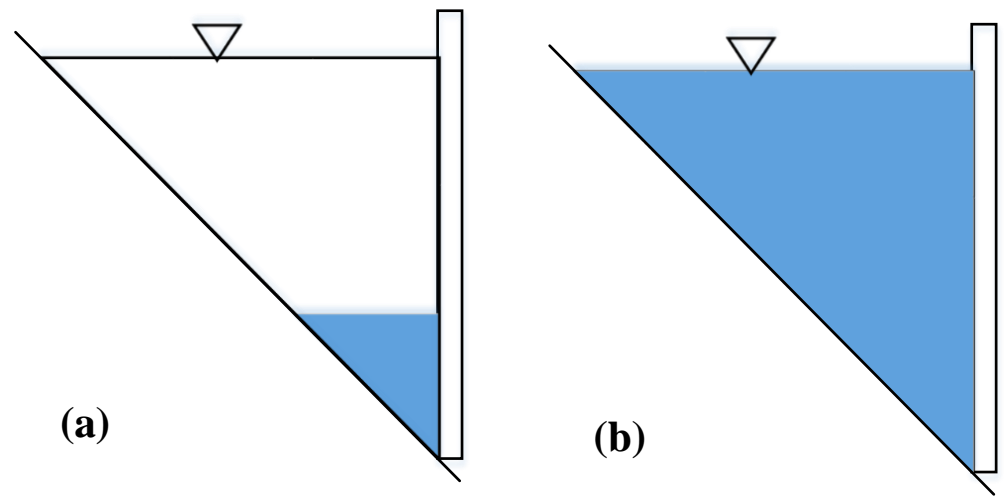

Figure 9. Sketch of the storage and discharge rules of small reservoirs (ponds), (a) is before the flood season, $(\mathbf{b})$ is after the flood season, inverted triangle is the normal water level for storage.

\section{Conclusions}

In this study, we investigated and quantified the impacts of climate change (precipitation, temperature, and sunshine duration) and anthropogenic activities (LUCC and DHAs) on the variations in AMS, Amax, and Amin in the CRB from 1967-2018, based on the WEP-L model and various simulation scenarios. The results indicate the following:

(1) Precipitation increased slightly at a rate of $24.8 \mathrm{~mm} /$ decade while temperature increased significantly at a rate of $0.23{ }^{\circ} \mathrm{C} /$ decade, and sunshine duration decreased at a rate of $-0.03 \mathrm{~h} /$ decade. AMS and Amin increased by 0.34 and $0.13 \mathrm{~m}^{3} / \mathrm{s} /$ decade, respectively, while Amax decreased at a rate of $-25.02 \mathrm{~m}^{3} / \mathrm{s} /$ decade during this period (1967 to 2018).

(2) Human activities reduced AMS and Amax more than climate change factors. Specifically, human activities increased Amin more than climate change reduced Amin. Anthropogenic activities play a major role in the variations of all three streamflow indicators.

(3) DHAs were the primary cause of changes in the three streamflow indictors, followed by precipitation, while the contribution rates of temperature, sunshine duration, and LUCC were much lower.

There are some limitations in this study, for example, due to the limitation of the datasets, we failed to separate the influences of each DHA (river water intake, inter-basin water transfer, and water conservancy project regulation and storage) on streamflow individually. On the other hand, we separated the impacts of climate change and anthropogenic activities on streamflow variation based on the assumption that the effect elements on streamflow were independent while ignoring the interaction impacts between climate change and anthropogenic activities, which should be discussed more in future research.

Author Contributions: Conceptualization, F.X.; methodology, F.X. and C.N.; software, F.X. and Y.Q.; writing—original draft preparation, F.X.; writing-review and editing, L.Z.; data curation, L.Z.; funding acquisition, F.X. and L.Z. All authors have read and agreed to the published version of the manuscript.

Funding: This research was funded by the Open Research Fund of State Key Laboratory of Simulation and Regulation of Water Cycle in River Basin, China Institute of Water Resources and Hydropower Research (IWHR-SKL-KF202018), National High-level Talents: WR0166A012019, GDAS' Project of Science and Technology Development (2020GDASYL-20200301003, 2020GDASYL-20200102002, 2020GDASYL-20200401001, 2020GDASYL-20200103008), National Natural Science Foundation of China (41771044).

Institutional Review Board Statement: Not applicable.

Informed Consent Statement: Not applicable.

Data Availability Statement: The study did not report any data. 
Conflicts of Interest: The authors declare no conflict of interest.

\section{References}

1. Dey, P.; Mishra, A. Separating the impacts of climate change and human activities on streamflow: A review of methodologies and critical assumptions. J. Hydrol. 2017, 548, 278-290. [CrossRef]

2. Xin, Z.; Li, Y.; Zhang, L.; Ding, W.; Ye, L.; Wu, J.; Zhang, C. Quantifying the relative contribution of climate and human impacts on seasonal streamflow. J. Hydrol. 2019, 574, 936-945. [CrossRef]

3. Xu, F.; Jia, Y.; Niu, C.; Liu, J.; Hao, C. Changes in Annual, Seasonal and Monthly Climate and Its Impacts on Runoff in the Hutuo River Basin, China. Water 2018, 10, 278. [CrossRef]

4. He, Y.; Hu, Y.; Song, J.; Jiang, X. Variation of runoff between southern and northern China and their attribution in the Qinling Mountains, China. Ecol. Eng. 2021, 171, 106374. [CrossRef]

5. Li, Y.; Liu, C.; Yu, W.; Tian, D.; Bai, P. Response of streamflow to environmental changes: A Budyko-type analysis based on 144 river basins over China. Sci. Total Environ. 2019, 664, 824-833. [CrossRef] [PubMed]

6. Gudmundsson, L.; Boulange, J.; Do, H.X.; Gosling, S.N.; Grillakis, M.G.; Koutroulis, A.G.; Leonard, M.; Liu, J.; Schmied, H.M.; Papadimitriou, L.; et al. Globally observed trends in mean and extreme river flow attributed to climate change. Science 2021, 371, 1159-1162. [CrossRef] [PubMed]

7. Luan, J.; Zhang, Y.; Ma, N.; Tian, J.; Li, X.; Liu, D. Evaluating the uncertainty of eight approaches for separating the impacts of climate change and human activities on streamflow. J. Hydrol. 2021, 601, 126605. [CrossRef]

8. Kazemi, H.; Hashemi, H.; Maghsood, F.F.; Hosseini, S.H.; Sarukkalige, R.; Jamali, S.; Berndtsson, R. Climate vs. Human Impact: Quantitative and Qualitative Assessment of Streamflow Variation. Water 2021, 13, 2404. [CrossRef]

9. AghaKouchak, A.; Feldman, D.; Hoerling, M.; Huxman, T.; Lund, J. Water and climate: Recognize anthropogenic drought. Nature 2015, 524, 409-411. [CrossRef]

10. Michalak, A.M. Study role of climate change in extreme threats to water quality. Nature 2016, 535, 349-350. [CrossRef]

11. Zhang, M.; Wei, X. Deforestation, forestation, and water supply. Science 2021, 371, 990-991. [CrossRef]

12. Xie, Z.; Mu, X.; Gao, P.; Wu, C.; Qiu, D. Impacts of Climate and Anthropogenic Activities on Streamflow Regimes in the Beiluo River, China. Water 2021, 13, 2892. [CrossRef]

13. Young, D.; Zégre, N.; Edwards, P.; Fernandez, R. Assessing streamflow sensitivity of forested headwater catchments to disturbance and climate change in the central Appalachian Mountains region, USA. Sci. Total Environ. 2019, 694, 133382. [CrossRef]

14. Yang, H.; Xiong, L.; Xiong, B.; Zhang, Q.; Xu, C.-Y. Separating runoff change by the improved Budyko complementary relationship considering effects of both climate change and human activities on basin characteristics. J. Hydrol. 2020, 591, 125330. [CrossRef]

15. Sun, W.; Song, X.; Zhang, Y.; Chiew, F.; Post, D.; Zheng, H.; Song, S. Coal Mining Impacts on Baseflow Detected Using Paired Catchments. Water Resour. Res. 2020, 56, e2019WR025770. [CrossRef]

16. Zeng, F.; Ma, M.-G.; Di, D.-R.; Shi, W.-Y. Separating the Impacts of Climate Change and Human Activities on Runoff: A Review of Method and Application. Water 2020, 12, 2201. [CrossRef]

17. Wang, S.; Wang, Y.; Ran, L.; Su, T. Climatic and anthropogenic impacts on runoff changes in the Songhua River basin over the last 56 years (1955-2010), Northeastern China. Catena 2015, 127, 258-269. [CrossRef]

18. Zhang, L.; Nan, Z.; Wang, W.; Ren, D.; Zhao, Y.; Wu, X. Separating climate change and human contributions to variations in streamflow and its components using eight time-trend methods. Hydrol. Process. 2019, 33, 383-394. [CrossRef]

19. Li, Z.; Huang, S.; Liu, D.; Leng, G.; Zhou, S.; Huang, Q. Assessing the effects of climate change and human activities on runoff variations from a seasonal perspective. Stoch. Environ. Res. Risk Assess. 2020, 34, 575-592. [CrossRef]

20. Zhai, R.; Tao, F. Contributions of climate change and human activities to runoff change in seven typical catchments across China. Sci. Total Environ. 2017, 605-606, 219-229. [CrossRef] [PubMed]

21. Ji, L.; Duan, K. What is the main driving force of hydrological cycle variations in the semiarid and semi-humid Weihe River Basin, China? Sci. Total Environ. 2019, 684, 254-264. [CrossRef] [PubMed]

22. Wu, L.; Zhang, X.; Hao, F.; Wu, Y.; Li, C.; Xu, Y. Evaluating the contributions of climate change and human activities to runoff in typical semi-arid area, China. J. Hydrol. 2020, 590, 125555. [CrossRef]

23. Zhang, H.; Meng, C.; Wang, Y.; Wang, Y.; Li, M. Comprehensive evaluation of the effects of climate change and land use and land cover change variables on runoff and sediment discharge. Sci. Total Environ. 2020, 702, 134401. [CrossRef] [PubMed]

24. Huo, J.; Liu, C.; Yu, X.; Jia, G.; Chen, L. Effects of watershed char and climate variables on annual runoff in different climatic zones in China. Sci. Total Environ. 2021, 754, 142157. [CrossRef]

25. Yang, Q.; Luo, S.; Wu, H.; Wang, G.; Han, D.; Lü, H.; Shao, J. Attribution Analysis for Runoff Change on Multiple Scales in a Humid Subtropical Basin Dominated by Forest, East China. Forests 2019, 10, 184. [CrossRef]

26. Konapala, G.; Mishra, A.K.; Wada, Y.; Mann, M.E. Climate change will affect global water availability through compounding changes in seasonal precipitation and evaporation. Nat. Commun. 2020, 11, 3044. [CrossRef]

27. Wu, Y.; Fang, H.; Huang, L.; Ouyang, W. Changing runoff due to temperature and precipitation variations in the dammed Jinsha River. J. Hydrol. 2020, 582, 124500. [CrossRef]

28. Yang, W.; Jin, F.; Si, Y.; Li, Z. Runoff change controlled by combined effects of multiple environmental factors in a headwater catchment with cold and arid climate in northwest China. Sci. Total Environ. 2021, 756, 143995. [CrossRef] 
29. Wang, D.; Hejazi, M. Quantifying the relative contribution of the climate and direct human impacts on mean annual streamflow in the contiguous United States. Water Resour. Res. 2011, 47, 411. [CrossRef]

30. Patterson, L.A.; Lutz, B.; Doyle, M.W. Climate and direct human contributions to changes in mean annual streamflow in the South Atlantic, USA. Water Resour. Res. 2013, 49, 7278-7291. [CrossRef]

31. Xu, X.; Yang, D.; Yang, H.; Lei, H. Attribution analysis based on the Budyko hypothesis for detecting the dominant cause of runoff decline in Haihe basin. J. Hydrol. 2014, 510, 530-540. [CrossRef]

32. Wang, X.; He, K.; Dong, Z. Effects of climate change and human activities on runoff in the Beichuan River Basin in the northeastern Tibetan Plateau, China. Catena 2019, 176, 81-93. [CrossRef]

33. Hou, J.; Ye, A.; You, J.; Ma, F.; Duan, Q. An estimate of human and natural contributions to changes in water resources in the upper reaches of the Minjiang River. Sci. Total Environ. 2018, 635, 901-912. [CrossRef] [PubMed]

34. Han, Z.; Long, D.; Fang, Y.; Hou, A.; Hong, Y. Impacts of climate change and human activities on the flow regime of the dammed Lancang River in Southwest China. J. Hydrol. 2019, 570, 96-105. [CrossRef]

35. Zhou, X.; Yang, Y.; Sheng, Z.; Zhang, Y. Reconstructed natural runoff helps to quantify the relationship between upstream water use and downstream water scarcity in China's river basins. Hydrol. Earth Syst. Sci. 2019, 23, 2491-2505. [CrossRef]

36. Huang, Z.; Yuan, X.; Liu, X. The key drivers for the changes in global water scarcity: Water withdrawal versus water availability. J. Hydrol. 2021, 601, 126658. [CrossRef]

37. Liang, W.; Bai, D.; Wang, F.; Fu, B.; Yan, J.; Wang, S.; Yang, Y.; Long, D.; Feng, M. Quantifying the impacts of climate change and ecological restoration on streamflow changes based on a Budyko hydrological model in China's Loess Plateau. Water Resour. Res. 2015, 51, 6500-6519. [CrossRef]

38. Chang, J.; Zhang, H.; Wang, Y.; Zhu, Y. Assessing the impact of climate variability and human activities on streamflow variation Hydrol. Earth Syst. Sci. 2016, 20, 1547-1560. [CrossRef]

39. Wang, D.; Yu, X.; Jia, G.; Wang, H. Sensitivity analysis of runoff to climate variability and land-use changes in the Haihe Basin mountainous area of north China. Agric. Ecosyst. Environ. 2019, 269, 193-203. [CrossRef]

40. Li, H.; Shi, C.; Sun, P.; Zhang, Y.; Collins, A.L. Attribution of runoff changes in the main tributaries of the middle Yellow River, China, based on the Budyko model with a time-varying parameter. Catena 2021, 206, 105557. [CrossRef]

41. Bai, P.; Liu, X.; Liang, K.; Liu, C. Investigation of changes in the annual maximum flood in the Yellow River basin, China. Quat. Int. 2016, 392, 168-177. [CrossRef]

42. Wang, W.; Zhang, Y.; Tang, Q. Impact assessment of climate change and human activities on streamflow signatures in the Yellow River Basin using the Budyko hypothesis and derived differential equation. J. Hydrol. 2020, 591, 125460. [CrossRef]

43. Mann, H. Non-parametric test against trend. Econometrika 1945, 13, 245-259. [CrossRef]

44. Kendall, M.G. Rank Correlation Measures; Charles Griffin: London, UK, 1975.

45. Pettitt, A.N. A Non-Parametric Approach to the Change-Point Problem. J. R. Stat. Soc. Ser. C (Appl. Stat.) 1979, $28,126-135$. [CrossRef]

46. Jia, Y.; Wang, H.; Zhou, Z.; Qiu, Y.; Luo, X.; Wang, J.; Yan, D.; Qin, D. Development of the WEP-L distributed hydrological model and dynamic assessment of water resources in the Yellow River basin. J. Hydrol. 2006, 331, 606-629. [CrossRef]

47. Jia, Y.; Ding, X.; Wang, H.; Zhou, Z.; Qiu, Y.; Niu, C. Attribution of water resources evolution in the highly water-stressed Hai River Basin of China. Water Resour. Res. 2012, 48, W02513. [CrossRef]

48. Xu, F.; Jia, Y.; Peng, H.; Niu, C.; Liu, J.; Hao, C.; Huang, G. Vertical zonality of the water cycle and the impact of land-use change on runoff in the Qingshui River Basin of Wutai Mountain, China. Hydrol. Sci. J. 2019, 64, 2080-2092. [CrossRef]

49. Xu, F.; Jia, Y.; Niu, C.; Sobkowiak, L.; Zhao, L. Evaluating spatial differences in the contributions of climate variability and human activity to runoff change in the Haihe River basin. Hydrol. Sci. J. 2021, 66, 2060-2073. [CrossRef]

50. Zhou, X.; Huang, G.; Piwowar, J.; Fan, Y.; Wang, X.; Li, Z.; Cheng, G. Hydrologic Impacts of Ensemble-RCM-Projected Climate Changes in the Athabasca River Basin, Canada. J. Hydrometeorol. 2018, 19, 1953-1971. [CrossRef]

51. Liu, J.; Zhou, Z.; Yan, Z.; Gong, J.; Jia, L.; Xu, C.Y.; Wang, H. A new approach to separating the impacts of climate change and multiple human activities on water cycle processes based on a distributed hydrological model. J. Hydrol. 2019, 578, 124096. [CrossRef]

52. Xu, F.; Zhao, L.; Jia, Y.; Niu, C.; Liu, X.; Liu, H. Evaluation of water conservation function of Beijiang River basin in Nanling Mountains, China, based on WEP-L model. Ecol. Indic. 2021, 134, 108383. [CrossRef]

53. Tong, S.; Li, X.; Zhang, J.; Bao, Y.; Bao, Y.; Na, L.; Si, A. Spatial and temporal variability in extreme temperature and precipitation events in Inner Mongolia (China) during 1960-2017. Sci. Total Environ. 2019, 649, 75-89. [CrossRef] [PubMed] 